\title{
Hydrological relationship between the North Atlantic Ocean and the Mediterranean Sea during the past 15 - 75 kyr
}

\author{
Martine Paterne, ${ }^{1}$ Nejib Kallel, ${ }^{1,2}$ Laurent Labeyrie, ${ }^{1}$ Maryline Vautravers, ${ }^{3}$ \\ Jean-Claude Duplessy, ${ }^{1}$ Martine Rossignol-Strick, ${ }^{4}$ Elsa Cortijo, 1 \\ Maurice Arnold, ${ }^{1}$ and Michel Fontugne ${ }^{1}$
}

\begin{abstract}
The Mediterranean Sea hydrology at the time of the Heinrich formation in the North Atlantic Ocean was analyzed by comparing sea surface temperatures (SSTs) and oxygen isotope composition of seawater ( $\delta w)$ changes during the past $75 \mathrm{kyr}$ in two marine cores. These were compared to the palynological variations derived in the Mediterranean Sea core. During the last glacial the two oceanic SST records show similar and synchronous patterns, with several long-term cooling periods, ending by abrupt SST increases. At the time of the Heinrich events, cold SSTs and low salinity prevailed in the Mediterranean Sea. The freshwater budget was similar to the modern one, permitting the presence of a mixed forest on the Mediterranean borderlands. The post-Heinrich periods are marked by a freshwater budget decrease, limiting oak and fir tree growth in the Mediterranean region. Increase of precipitation or reduction of evaporation is observed before the Heinrich episode, and is associated with a well-developed mixed Mediterranean forest.
\end{abstract}

\section{Introduction}

Recent paleoceanographic investigations have shown that the hydrological changes in the North Atlantic Ocean and in the Mediterranean Sea were directly connected over the past $18 \mathrm{kyr}$, except at $\sim \mathbf{8 5 0 0} \mathrm{ka}$ during the formation of Sapropel S1 [Kallel et al., 1997a, b]. During the last glacial period the North Atlantic area experienced several abrupt climatic changes known as Heinrich events in the marine sediments [Heinrich, 1988; Broecker et al., 1992; Bond et al., 1992, 1993] and DansgaardOeschger events in marine and ice cores [Dansgaard et al., 1993; Bond and Lotti, 1995; Rasmussen et al., 1996]. Associated detritals in the marine environment are restricted to an ice-rafted belt between $40^{\circ}$ and $55^{\circ} \mathrm{N}$ [Ruddiman, 1977]. They are related to massive discharges of icebergs originating from the Baffin Bay and/or the Arctic/northern Eurasian areas [Grousset et al., 1993; Gwiazda et al., 1996; Revel et al., 1996].

The resulting low-salinity anomalies of the surface waters subsequently affected the North Atlantic Deep Water production [Oppo and Lehman, 1995; Sarnthein et al., 1994; Vidal et al., 1997; Zahn et al., 1997; Vidal et al., 1998], and consequently,

\footnotetext{
'Laboratoire des Sciences du Climat et de l'Environnement, Unité mixte CNRS-CEA, Gif sur Yvette, France.

${ }^{2}$ Now at Département des Sciences de la Terre, Université de Sfax, Sfax, Tunisia.

${ }^{3}$ Département de Géologie et Océanographie, Université de Bordeaux I, Talence, France.

'Laboratoire de Paléontologie et Palynologie, Université Pierre et Marie Curie, Paris, France.

Copyright 1999 by the American Geophysical Union.

Paper number 1998PA900022.

0883-8305/99/1998PA900022\$12.00
}

the North Atlantic heat pump weakened. In the same time, the climate of the surrounding continental areas would be modified by changes of the atmospheric and associated moisture transports during these events [Grimm et al., 1993; Guiot et al., 1993; Watts et al., 1996a].

The aim of this paper is to analyze the hydrological behavior of the Mediterranean area at the time of the huge ice sheet calvings in the North Atlantic Ocean. Detailed oxygen isotope analyses of planktonic foraminifera $\left(\delta^{18} \mathrm{O}\right)$, sea surface temperatures (SSTs) and seawater $(\delta w)$ records were developed on two well-dated deep-sea sediment cores collected in the icerafted belt in the North Atlantic Ocean and in the Tyrrhenian Sea (Figure 1). Moreover, the Tyrrhenian Sea core yielded a pollen record [Rossignol-Strick and Planchais, 1989], which allows direct comparison of the continental and marine climatic conditions prevailing outside the immediate North Atlantic region during the last glacial.

\section{Methods}

We derived an abolute chronology by using ${ }^{14} \mathrm{C}$ age calibration [Stuiver and Reimer, 1993; Mazaud et al., 1991] in order to compare the hydrological changes in the North Atlantic Ocean and in the Tyrrhenian Sea. Procedure to derive seawater $\delta^{18} \mathrm{O}(\delta \mathrm{w})$ changes has already been described [Labeyrie et al., 1986; Duplessy et al., 1991; Maslin et al., 1995; Kallel et al., 1997a]. It is based on SST estimates and on measurements of oxygen isotope compositions of planktonic foraminiferal shells which reflect changes of 1 ) the global ocean water $\delta w$ composition due to ice volume fluctuations, 2) the local sea surface $\delta w$ due to the freshwater budget (precipitation $\mathbf{P}+$ runoff $\mathbf{R} /$ evaporation $\mathbf{E}$ ), and 3 ) the isotopic fractionation between calcium carbonate and water, which depends upon the temperature $\mathrm{T}^{*}$ at which foraminifera form their tests [Epstein, 1953; Shackleton, 1974]. 


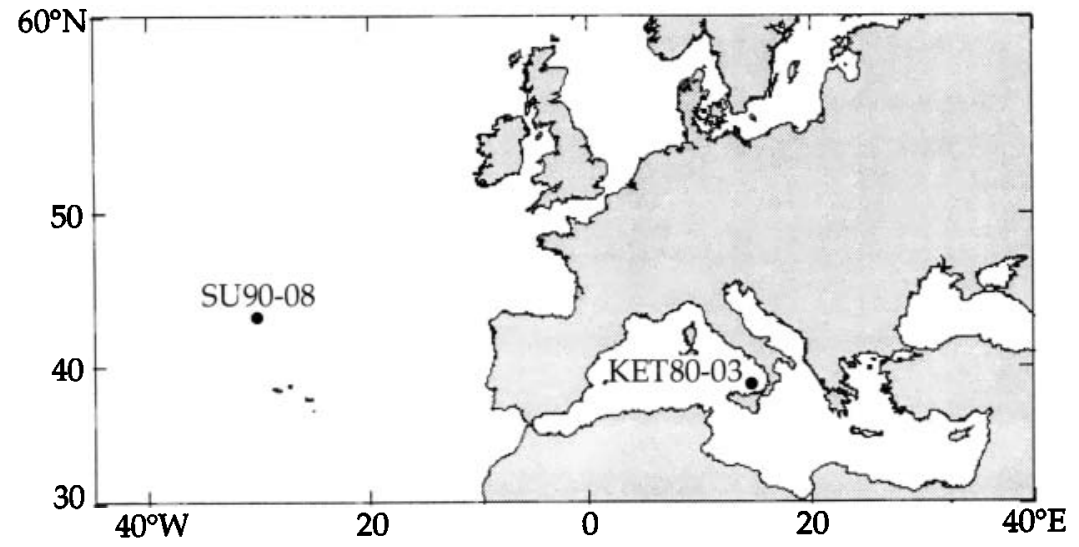

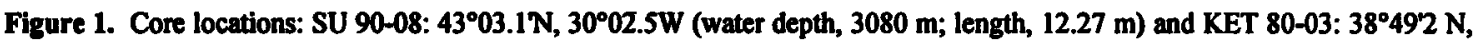
$14^{\circ} 29^{\prime} 5 \mathrm{E}$ (water depth, $1900 \mathrm{~m}$; length, $10.10 \mathrm{~m}$ ).

\subsection{Chronology}

Accelerator mass spectrometry (AMS) ${ }^{14} \mathrm{C}$ datings were performed on monospecific foraminifera in the two cores (Figures 2, 3, and 4 and Table 1). An additionnal dating in the North Atlantic Ocean core SU 90-08 was provided by the identification of the well-dated Ash Zone I [Bard et al., 1993]. Furthermore, Ash Zone II was also recognized in this core, the age of which was estimated at $\sim 57.5 \mathrm{ka}$ [Smythe et al., 1985]. In the Tyrrhenian Sea core KET 80-03, additional datings were provided by the $\mathrm{K} / \mathrm{Ar}$ ages of some Italian pyroclastic eruptions, geochemically identified in the central Mediterranean Sea sediments [Paterne et al., 1986; 1988]. Because of the presence of such absolute ages, the ${ }^{14} \mathrm{C}$ ages were thus expressed in

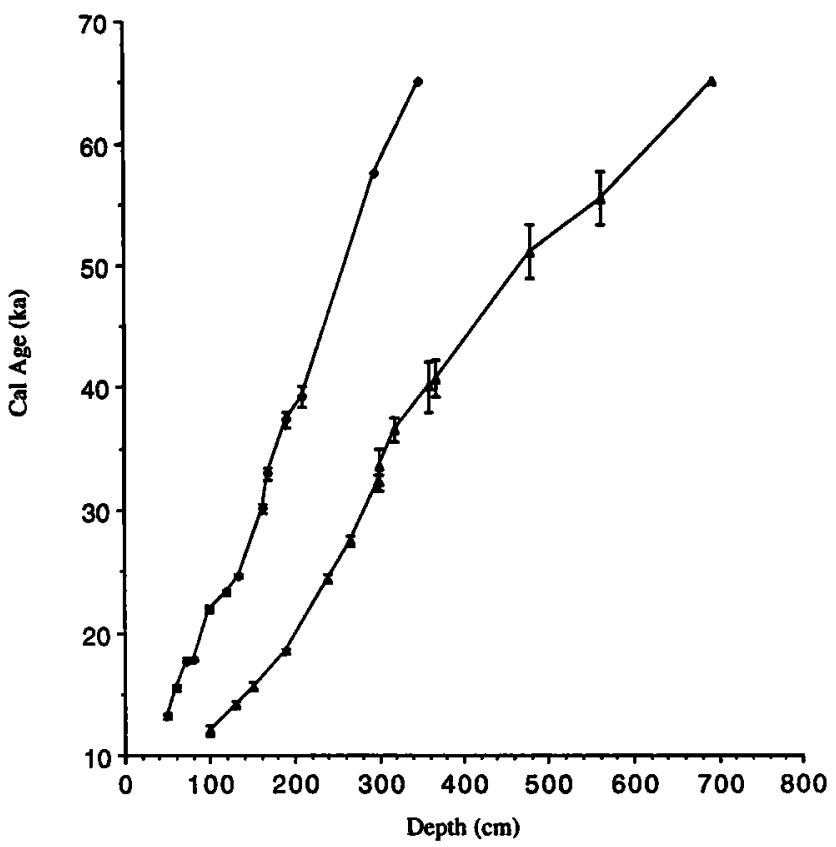

Figure 2. Calendar age (CAL)-depth relation in cores SU 90-08 (solid diamonds) and KET 80-03 (solid triangles). calendar ages for the past 18 kyr using Stuiver and Reimer's [1993] calib 3.0 program. Below $18 \mathrm{ka}$ a magnetic correction has been applied to the ${ }^{14} \mathrm{C}$ ages [Mazaud et al., 1991]. We assumed a constant reservoir age of the surface waters ( 400 years) through time in the two oceanic areas, though such an assumption may generate errors of up to 800 years in the North Atlantic Ocean [Bard et al., 1993; Austin et al., 1994]. The age of the oxygen isotope subevent 4.2 was fixed at $65 \mathrm{ka}$ [Imbrie et al., 1982] and of the oxygen isotope transition 4.0 was fixed at $62 \mathrm{ka}$, as an average of the ages obtained by linear interpolation (Figures 2, 3 and 4). Chronology was then assessed by linear interpolations between two dated levels in each core. Time resolution of the sampling interval is $\sim 550$ years in both cores, with a $2 \mathrm{~cm}$ sampling interval in core SU $90-08$ and a $5 \mathrm{~cm}$ one in core KET 80-03. In the last core, resolution increased to some 300 years from 500 to $680 \mathrm{~cm}$.

\subsection{Sea Surface Temperature Estimates}

The North Atlantic Ocean and Tyrrhenian Sea SSTs were estimated using the modem analog technique [Hutson, 1979; Prell, 1985] (Figures 3 and 4). Method and derived SST estimates were previously presented for core SU 90-08 [Cortijo et al., 1997] and for the past $18 \mathrm{kyr}$ for core KET 80-03 [Kallel et al., 1997a, b].

In core SU 90-08, SST estimates are based on good modern analogs with dissimilarity coefficients mainly lower than 0.15 [Overpeck et al., 1985]. Nevertheless, SST values with standard deviations larger than $2.5^{\circ} \mathrm{C}$ have not been taken into account in further seawater $\delta 180$ calculations. In core KET $80-03$, modern analogs are mainly found in the North Atlantic Ocean during glacial conditions. Dissimilarity coefficients are larger than in core SU 90-08 but rarely exceed 0.25 (Figure 3) because of the coexistence of foraminifera characteristic of the North Atlantic Ocean and the Mediterranean Sea. This feature is enhanced by bioturbation effects, as dissimilarity coefficients increase when sea surface temperatures vary abruptly (Figure 4). Thus we considered that SST estimates are reliable along the Tyrrhenian Sea core, except when standard deviations are larger than $2^{\circ} \mathrm{C}$. 


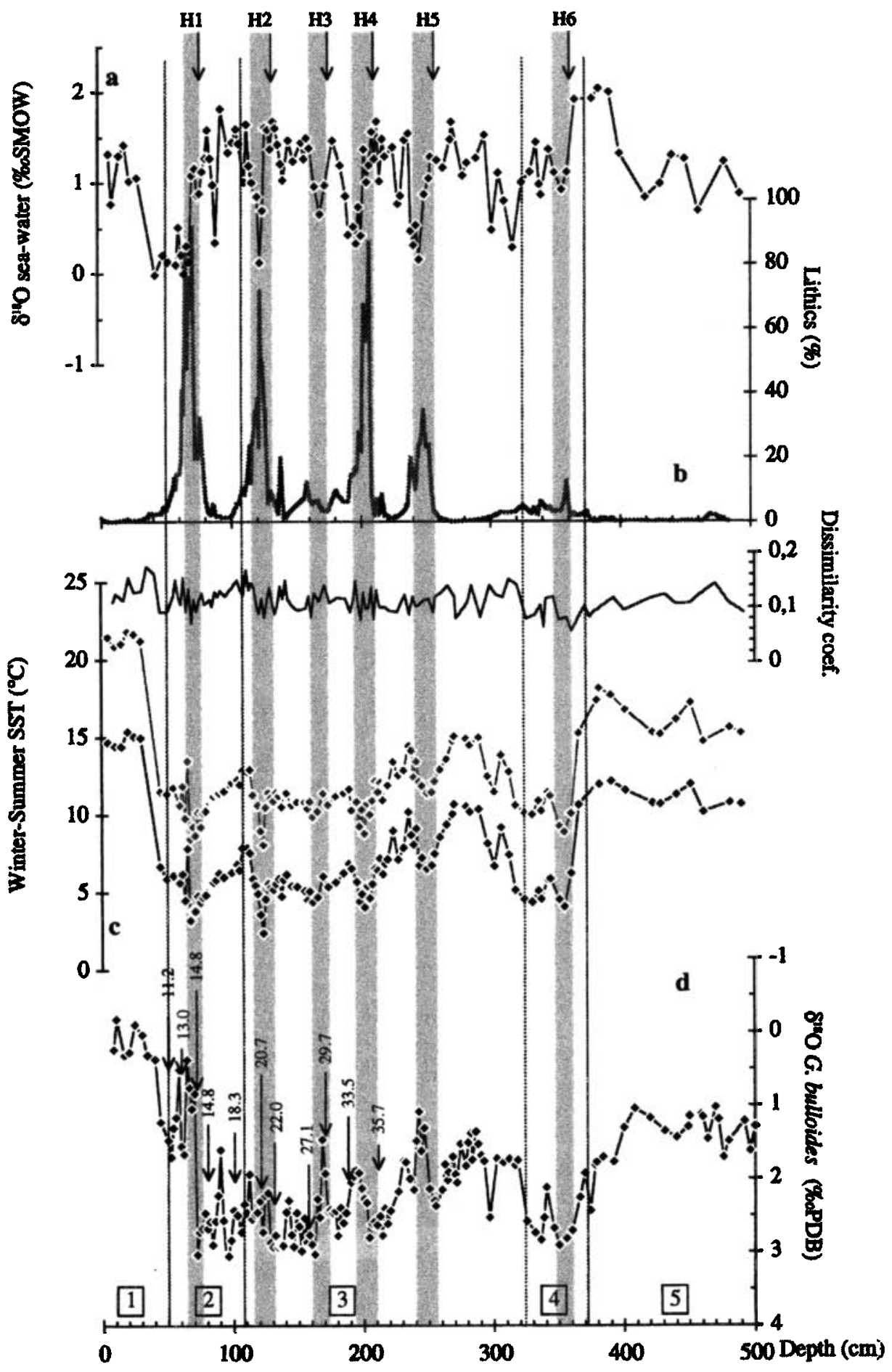

Figure 3. Plot of (a) seawater $\delta w$ (\% SMOW) (diamond line, left axis) and the lithics abundance (per cent) (shaded line, right axis), (b) winter and summer sea surface temperatures SSTs (degrees celsius) (solid diamond and shaded diamond lines, left axis) and dissimilarity coefficients (solid line, right axis), and (c) $\delta^{18} \mathrm{O}$ (\%o Pee Dee belemnite (PDB) record of Globigerina bulloides as a function of depth in North Atlantic deep-sea core SU 90-08. Sampling interval for SST data is $2 \mathrm{~cm}$ until $260 \mathrm{~cm}$ and $10 \mathrm{~cm}$ below. Oxygen isotope stage boundaries are also shown. Dashed areas represent the Heinrich events from $\mathrm{H1}$ to $\mathrm{H6}$, defined by the increase of the magnetic susceptibility and of ice-rafted detritals [Grousset et al., 1993; Vautravers, 1997], except for $\mathrm{H} 3$ marked by a $\delta \mathrm{w}$ low (see text). The ${ }^{14} \mathrm{C}$ datings are reported. 


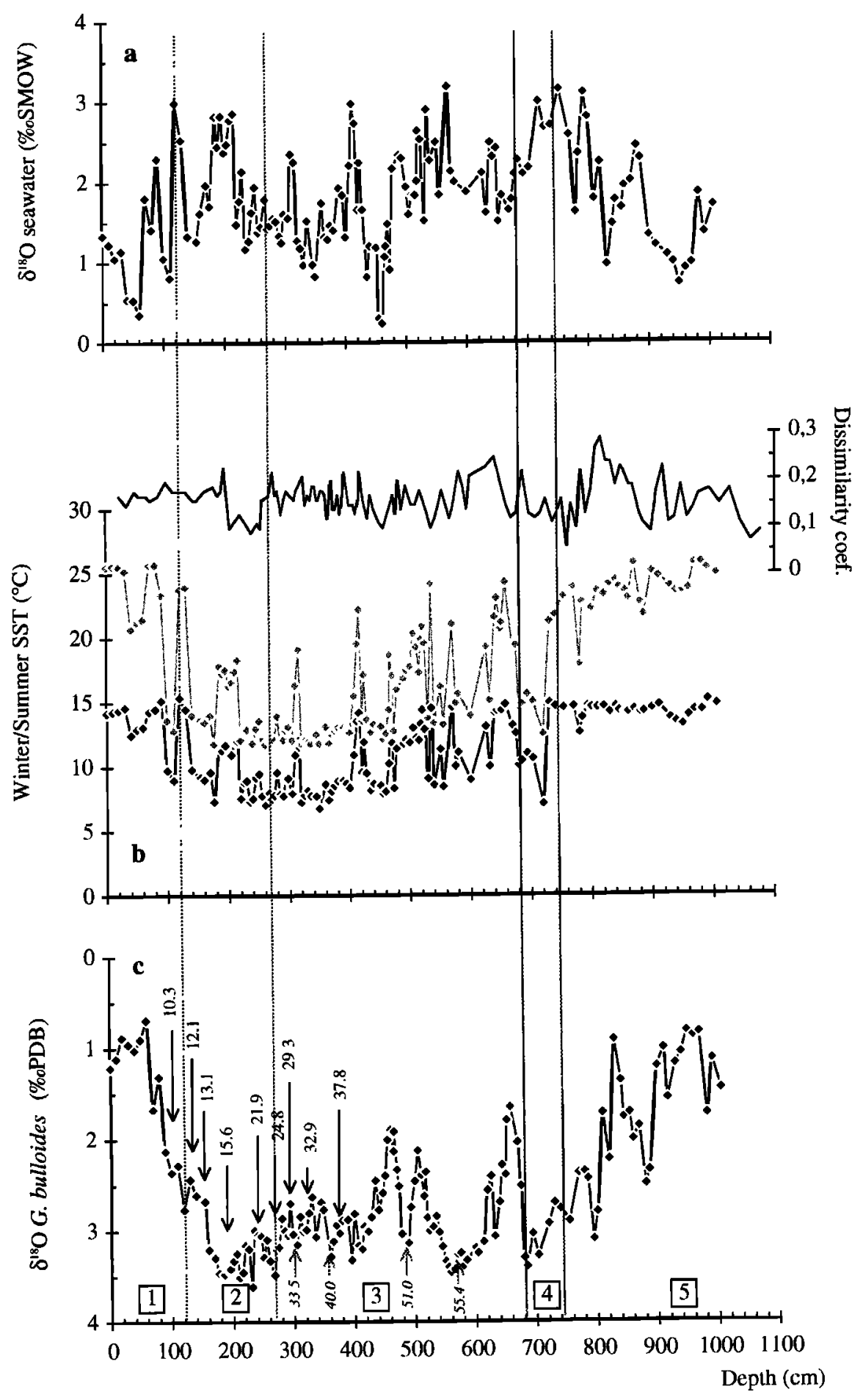

Figure 4. Plot of (a) seawater $\delta w$ (\% SMOW), (b) winter and summer SST (degrees celsius) (solid diamonds and shaded diamonds lines, left axis) and dissimilarity coefficient (solid line, right axis), and (c) $\delta^{18} \mathrm{O}$ (\%o PDB) record of $G$. bulloides as. a function of depth in the Tyrnhenian deep-sea core KET 80-03. Oxygen isotope stage boundaries and the ${ }^{4} \mathrm{C}$ and $\mathrm{K} / \mathrm{Ar}$ (in italics) datings are also reported. 
Table 1. AMS ${ }^{14} \mathrm{C}$ Datings on Neogloboquadrina pachyderma left in Core SU 90-08 and Globigerina bulloides in Core KET 80-03, Picked in the Peaks of Abundance

\begin{tabular}{|c|c|c|c|c|c|c|c|c|c|}
\hline \multicolumn{5}{|c|}{ SU 90-08 } & \multicolumn{5}{|c|}{ KET 80-03 } \\
\hline Depth & AMS ${ }^{14} \mathrm{C}$ & $1 \sigma$ & Cal Ages & $1 \sigma$ & Depth & AMS ${ }^{14} \mathrm{C}$ & $1 \sigma$ & Cal Ages & $1 \sigma$ \\
\hline $50^{2}$ & $11.20^{\mathrm{a}}$ & $0.15^{a}$ & $13.20^{\mathrm{a}}$ & $0.16^{2}$ & 100 & 10.27 & 0.16 & 11.99 & $+0.25 /-0.43$ \\
\hline 60 & 13.04 & 0.11 & 15.50 & 0.22 & 130 & 12.14 & 0.18 & 14.17 & 0.27 \\
\hline 72 & 14.83 & 0.11 & 17.73 & 0.15 & 150 & 13.10 & 0.20 & 15.58 & 0.35 \\
\hline 80 & 14.88 & 0.10 & 17.79 & 0.14 & 190 & 15.59 & 0.19 & 18.49 & 0.20 \\
\hline 100 & 18.33 & 0.15 & 21.89 & 0.25 & 240 & 21.89 & 0.39 & 24.39 & \\
\hline 120 & 20.70 & 0.21 & 23.33 & & 267 & 24.84 & 0.42 & 27.46 & \\
\hline 134 & 22.05 & 0.20 & 24.60 & & 298 & 29.30 & 0.59 & 32.20 & \\
\hline 162 & 27.08 & 0.33 & 30.10 & & 300 & 29.30 & 0.70 & 32.20 & \\
\hline 170 & 29.69 & 0.51 & 32.95 & & $300^{2}$ & & $1.50^{\mathrm{a}}$ & $33.50^{\mathrm{a}}$ & \\
\hline 192 & 33.45 & 0.66 & 37.33 & & 320 & 32.87 & 0.97 & 36.49 & \\
\hline 210 & 35.73 & 0.88 & 39.20 & & $360^{a}$ & & $2.00^{\circ}$ & $40.00^{\circ}$ & \\
\hline $297^{2}$ & & & $57.50^{3}$ & & 370 & 37.80 & 1.50 & 40.68 & \\
\hline \multirow[t]{3}{*}{$350^{b}$} & & & $65.00^{b}$ & & $480^{a}$ & & $2.20^{\mathrm{a}}$ & $51.00^{\mathrm{a}}$ & \\
\hline & & & & & $562^{\mathrm{a}}$ & & $2.20^{\mathrm{a}}$ & $55.40^{\mathrm{a}}$ & \\
\hline & & & & & $694^{b}$ & & & $65.00^{b}$ & \\
\hline
\end{tabular}

AMS, accelerator mass spectrometry; Cal, calendar ages. The AMS ${ }^{14} \mathrm{C}$ dating at depth $72 \mathrm{~cm}$ in core SU 90-08 has been considered too old and has not been not taken into account.

- Ages referred to tephra layers.

- Ages correspond to Milankovitch ages of oxygen isotope subevent 4.2 [Imbrie et al., 1982].

\subsection{Planktonic $\left(\delta^{18} 0\right)$ and Seawater $(\delta w)$ Oxygen Isotope Compositions}

Oxygen isotope records are developed from Globigerina bulloides picked in the 250-315 $\mu \mathrm{m}$ size in both cores. The North Atlantic Ocean record was previously presented [Grousset et al., 1993; Cortijo et al., 1997] and is here restricted to the interval from Holocene to oxygen isotope stage transition $4 / 5$ (Figure 3).

The modern seawater ( $\delta w)$ oxygen isotope values are estimated using the modern salinity values [Levitus, 1982] and the modem

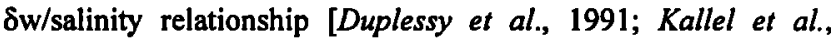
1997a]. They are estimated at $0.7 \%$ for a salinity of $S=35.9$ and at $1.4 \%$ for $S=38.03$ at core sites in the North Atlantic Ocean and in the Mediterranean Sea, respectively. A $0.5 \%$ ow change corresponds to a 1 and a 1.22 salinity change, respectively. Past $\delta w$ values were estimated by solving the paleotemperature equation [Shackleton, 1974], using the optimal growth temperature $T^{*}$ [Duplessy et al., 1991]. For the species $G$. bulloides it is equivalent to $\mathrm{T}^{*}=$ summer SST $-1^{\circ} \mathrm{C}$ in the range $7^{\circ}-22^{\circ} \mathrm{C}$ in the North Atlantic Ocean [Duplessy et al., 1991] and to $T^{*}=$ April-May SST in the range $14^{\circ}-16^{\circ} \mathrm{C}$ in the Mediterranean Sea [Kallel et al., 1997a].

During the past $75 \mathrm{kyr}$, summer SST fluctuations vary from $8^{\circ}$ to $22^{\circ} \mathrm{C}$ in core SU 90-08 (Figure 2). They cover the whole range of the SST calibration of $T^{*}$ for $G$. bulloides in the North Atlantic Ocean [Duplessy et al., 1991]. Thus the isotopic temperature $\mathrm{T}^{*}=$ summer SST $-1^{\circ} \mathrm{C}$ will be used to calculate the $\delta w$ compositions in the North Atlantic Ocean core (Figure 3). In the Mediterranean Sea core, April-May SSTs vary from $8^{\circ}$ to $17^{\circ} \mathrm{C}$ (Figure 4), mainly below the calibration temperature range of $\mathrm{T}^{*}$ in the Mediterranean Sea $\left(14^{\circ}-16^{\circ} \mathrm{C}\right)$ [Kallel et al., 1997a]. Nevertheless, we assumed that the seasonal bloom in the
Mediterranean Sea occurred within the optimal temperature range determined in the North Atlantic Ocean [Duplessy et al., 1991]. Taking into account the $0.07 \%$ error due to mass spectrometer measurements and the mean standard deviation on SSTs, the averaged errors on the $\delta w$ estimates are $0.45 \%$ for the Tyrrhenian Sea $\left(\sigma_{S S T s}=1.14^{\circ} \mathrm{C}\right)$ and $0.60 \%$ for the North Atlantic Ocean $\left(\sigma \mathrm{SSTs}=1.79^{\circ} \mathrm{C}\right)$.

\section{Results}

Within the absence of any sedimentological signature of the Heinrich events in the Mediterranean Sea the study of the climatic conditions during these events in this area basically rests on chronology. We briefly present the chronology of the North Atlantic Ocean paleohydrological records as they were previously discussed in detail [Grousset et al., 1993; Cortijo, 1995; Cortijo et al., 1997; Vidal et al., 1997; Elliot et al., 1998]. The stratigraphical position of the Heinrich events in the Mediterranean Sea was then assessed by comparing the North Atlantic Ocean and Mediterranean Sea paleohydrological records before analyzing the climatic response of the Mediterranean area to the short-term climatic variability in the North Atlantic Ocean.

\subsection{Heinrich Events in the North Atlantic Ocean Core SU 90-08}

In the North Atlantic Ocean the Heinrich events are characterized by an increase of the abundance of coarse lithics, by cold SSTs, by depleted $\delta^{180}$ values of the planktic foraminifera, and by low $\delta w$ values [Heinrich, 1988; Broecker et al., 1992; Bond et al., 1992, 1993; Maslin et al., 1995].

Such features are recognizable in core SU 90-08 (Figures 3 and 5). Peaks of abundant lithic concentrations were identified and 


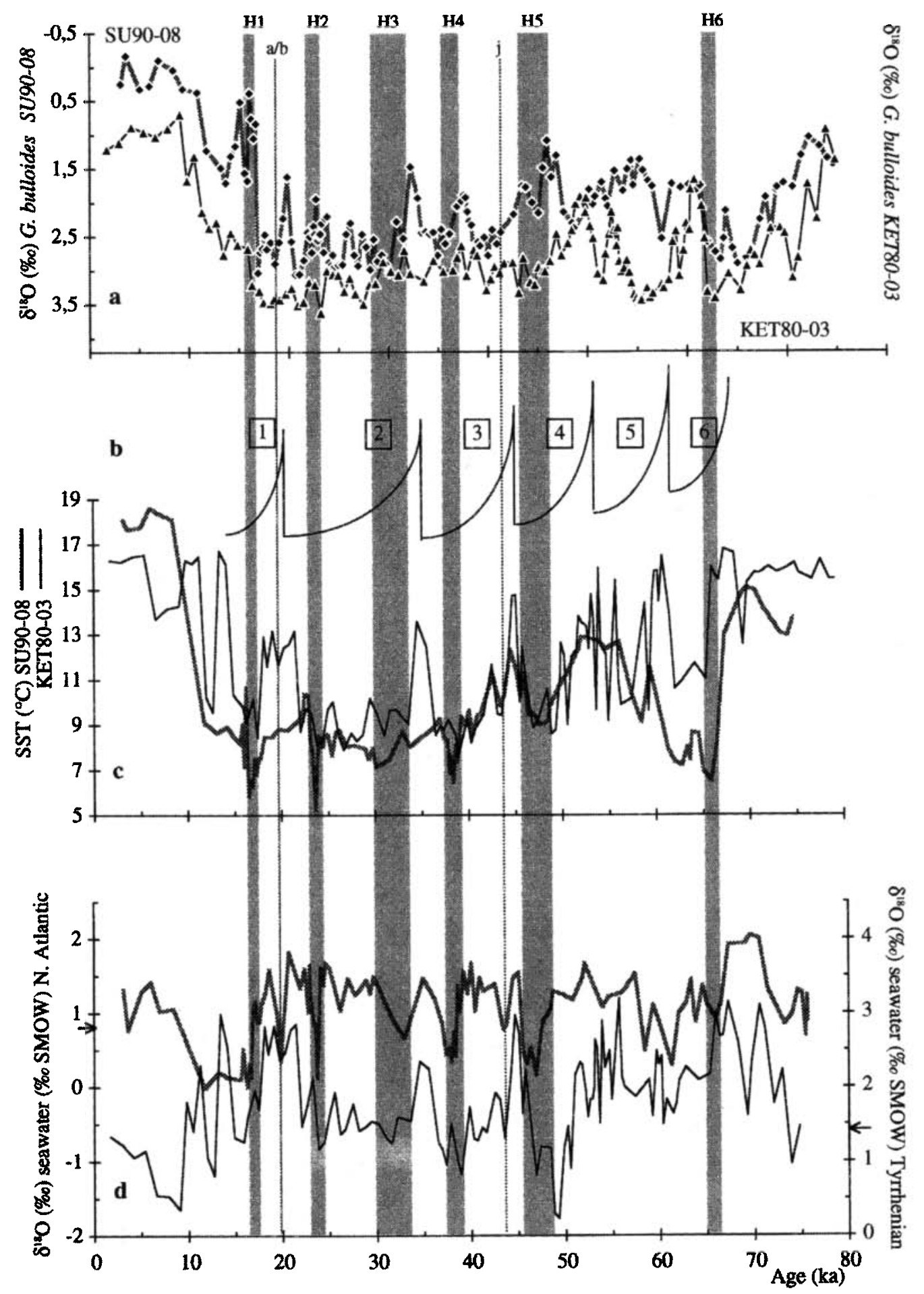

Figure 5. Plot of (a) the $\delta^{18} \mathrm{O}$ (\% PDB) record of $G$. bulloides in cores SU 90-08 (dotted line, solid diamonds, left axis) and KET 80-03 (solid line and solid triangles), (b) the long-term cooling cycles from 1 to 6 (see text), (c) the North Atlantic Ocean

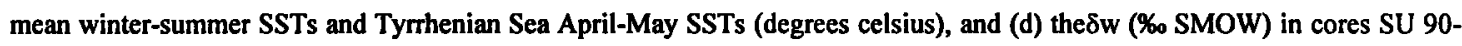
08 (dotted line) and KET 80-03 (solid line) as a function of age in ka. Positions of the Heinrich events are presented (vertical dashed areas). Arrows on the $y$ axis represent the modern $\delta w$ values (see text). 
Table 2. AMS ${ }^{14} \mathrm{C}$ and Calendar ka Ages of the Onset and End of the Heinrich Events in Core SU 90-08 and of the Main $\delta$ w Changes in Core KET 80-03

\begin{tabular}{|c|c|c|c|c|c|c|c|c|}
\hline & \multicolumn{4}{|c|}{ SU 90-08 } & \multicolumn{4}{|c|}{ KET 80-03 } \\
\hline & Depth, c & $\begin{array}{r}\text { AMS }{ }^{14} \mathrm{C} \\
(-400 \text { years })\end{array}$ & $1 \sigma$ & Cal Age & Depth, cm & $\begin{array}{l}\text { AMS } \\
(-400\end{array}$ & 10 & Cal Age \\
\hline Hl & $\begin{array}{l}65 \\
75\end{array}$ & $\begin{array}{l}13.47 \\
14.65\end{array}$ & $\begin{array}{l}0.15 \\
0.15\end{array}$ & $\begin{array}{l}16.15 \\
17.30\end{array}$ & $\begin{array}{l}120 \\
180\end{array}$ & $\begin{array}{l}11.50 \\
15.00\end{array}$ & $\begin{array}{l}0.24 \\
0.28\end{array}$ & $\begin{array}{l}13.44 \\
17.76\end{array}$ \\
\hline $\mathrm{a} / \mathrm{b}$ ? & 90 & 16.60 & 0.18 & 19.84 & & & & \\
\hline H2 & $\begin{array}{l}115 \\
130\end{array}$ & $\begin{array}{l}20.10 \\
21.66\end{array}$ & $\begin{array}{l}0.26 \\
0.26\end{array}$ & $\begin{array}{l}22.96 \\
24.22\end{array}$ & $\begin{array}{l}220 \\
245\end{array}$ & $\begin{array}{l}19.40 \\
22.40\end{array}$ & $\begin{array}{l}0.43 \\
0.57\end{array}$ & $\begin{array}{l}22.03 \\
24.96\end{array}$ \\
\hline $\mathrm{H} 3$ & $\begin{array}{l}160 \\
175\end{array}$ & $\begin{array}{l}26.70 \\
30.40\end{array}$ & $\begin{array}{l}0.55 \\
0.51\end{array}$ & $\begin{array}{r}29.70 \\
33.75\end{array}$ & 305 & 30.20 & 0.72 & 33.57 \\
\hline H4 & $\begin{array}{l}191 \\
210\end{array}$ & $\begin{array}{l}32.50 \\
35.73\end{array}$ & $\begin{array}{l}1.00 \\
0.88\end{array}$ & $\begin{array}{l}37.10 \\
39.20\end{array}$ & $\begin{array}{l}320 \\
355\end{array}$ & $\begin{array}{l}32.87 \\
35.30\end{array}$ & $\begin{array}{l}0.97 \\
1.80\end{array}$ & $\begin{array}{l}36.49 \\
39.30\end{array}$ \\
\hline j? & 232 & & & 43.80 & 407 & & 1.80 & 44.20 \\
\hline $\mathrm{H} 5 / \mathrm{S} 2$ & $\begin{array}{l}240 \\
255\end{array}$ & & & $\begin{array}{l}45.50 \\
48.70\end{array}$ & $\begin{array}{l}430 \\
475\end{array}$ & & $\begin{array}{l}2.70 \\
2.70\end{array}$ & $\begin{array}{l}46.40 \\
50.72\end{array}$ \\
\hline MED & & & & & $\begin{array}{l}500 \\
520\end{array}$ & & $\begin{array}{l}3.00 \\
3.00\end{array}$ & $\begin{array}{l}52.11 \\
53.12\end{array}$ \\
\hline H6 & 360 & & & 66.50 & 710 & & & 65.60 \\
\hline
\end{tabular}

related to the Heinrich events, except for H3 [Grousset et al., 1993; Cortijo, 1995]. They are related to cold SSTs and low $\delta w$ values. They ended with a rapid warming of the surface waters. The ${ }^{14} \mathrm{C}$ ages of $\mathrm{H} 1, \mathrm{H} 2$, and $\mathrm{H} 4$ correspond well with previous datings (Table 2) [Bond et al., 1992, 1993; Andrews and Tedesco, 1992; Andrews et al., 1994; Manighetti et al., 1995; Cortijo et al., 1997; Vidal et al., 1997; Zahn et al., 1997]. The calibrated ages also agree with the ages obtained by the correlation of Greenland Ice Sheet Project 2 (GISP) and North Atlantic Ocean records [Bond and Lotti, 1995]. Although comparable considering dating errors, the ages of the $\mathrm{H} 3$ boundaries show a systematic aging in core SU 90-08 with respect to datings in other North Atlantic Ocean cores [Bond et al., 1992, 1993]. However, in this core, $\mathrm{H3}$ is defined neither by a peak of susceptibility nor by an increase of ice-rafted debris [Grousset et al., 1993] but by a $\delta w$ low. Since their discovery several pulses of ice-rafted debris have been recognized in addition to H1-H6 events in both the North Atlantic Ocean [Bond and Lotti, 1995; Elliot et al., 1998] and the Norwegian Sea [Bauman et al., 1995; Fronval et al., 1995; Rasmussen et al., 1996]. Thus the $\delta w$ depletion we noticed at $\mathrm{H} 3$ could be synchronous to other previous ice-rafted discharges ( $f, g$, and $h$ events given by Bond and Lotti [1995]). Similar $\delta \mathrm{w}$ decreases, unrelated to detritic material, occurred in core SU 90-08 at $\sim 19$ and 44 calendar ka (Figures 2, 4 and 5 and Table 2). We tentatively related them to the $a / b$ and $j$ events, respectively, observed in the North Atlantic Ocean cores [Bond et al., 1993; Bond and Lotti, 1995].

\subsection{Chronological Comparison of the Tyrrhenian Sea and North Atlantic Ocean Hydrological Records}

We compared the timing of the SST, foraminiferal $\delta^{18} \mathrm{O}$, and $\delta w$ changes in cores SU 90-08 and KET 80-03 without any stratigraphical adjustment between the two cores. First-order changes of SST and foraminiferal $\delta^{180}$ values are well marked and nearly synchronous in the two marine areas (Figure 5). By contrast, the timing of second-order $\delta^{180}$ changes in the two cores is markedly different, for example, from 40 to $50 \mathrm{ka}$, whereas the associated SST changes are almost synchronous. As a result, the calculated short-term $\delta w$ changes show a different pattern in the two oceanic regions. The Mediterranean Sea record reveals several long-term $\delta w$ decreases followed by rapid $\delta w$ increases. By contrast, the North Atlantic Ocean $\delta w$ record exibits rapid fluctuations of short duration, as observed in the northeast Atlantic Ocean [Maslin et al., 1995].

In the time interval 15-75 ka the Tyrrhenian Sea sediments recorded long progressive cooling phases, ending by a steep SST increase (cycles $1-6$ in Figure 4). Such a pattern is strongly similar to that described in the North Atlantic Ocean as the longer-term cooling cycles [Bond et al., 1993] (Figure 5). The North Atlantic Ocean SST warmings systematically lead the Tyrrhenian Sea ones after H4, H2, and H1. Nevertheless, the time offsets are $\sim 1.2 \pm 1.5,1.2 \pm 0.55$, and $1.0 \pm 0.48 \mathrm{ka}$, respectively, (at $1 \sigma$ ), which lie within uncertainties linked to dating, time resolution of the sampling interval, and bioturbation effects. Moreover, these offsets could also be due to variations of the 


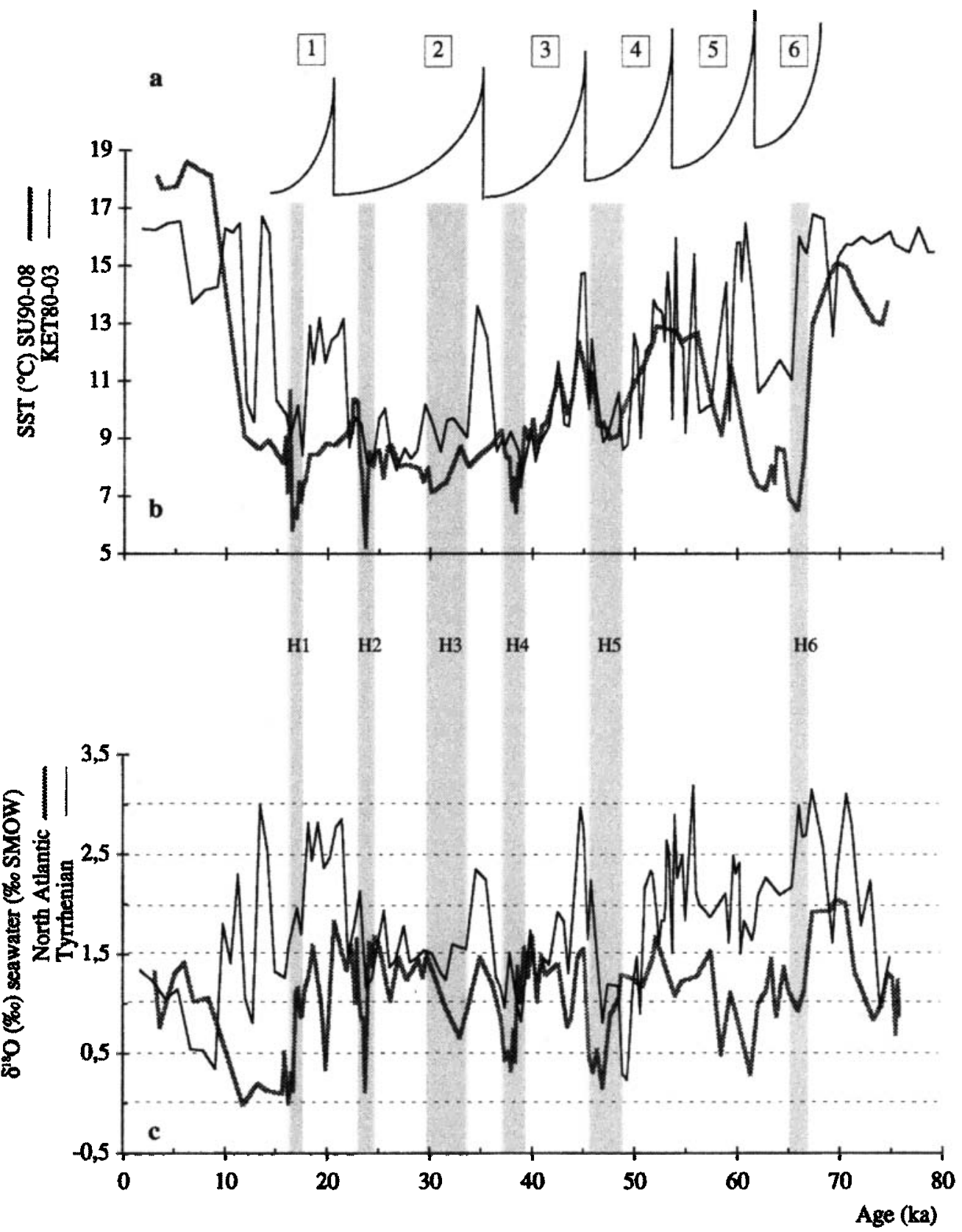

Figure 6. Plot of (a) the long-term cooling cycles from 1 to 6 (see text), (b) the North Atlantic Ocean mean winter-summer SSTs and Tyrrhenian Sea April-May SSTs (degrees celsius), and (c) the $\delta w$ (\% SMOW) in cores SU 90-08 (dotted line) and KET 80-03 (solid line) as a function of age in ka. Positions of the Heinrich events are presented (vertical dashed areas).

reservoir age of the North Atlantic Ocean surface waters [Bard et al., 1993]. Considering the overall dating uncertainties, we estimated that the observed chronological shifts between the two SST records are not significant. Furthermore, we did not perform any stratigraphical adjustment between the two cores according to the good similarity of the two SST patterns. We therefore assume that the end of the Heinrich events in both the Mediterranean Sea and the North Atlantic Ocean coincides with the rapid step of SST increase, and the Heinrich event corresponds to the preceeding cold time interval.

\subsection{Hydrology of the Mediterranean Sea at the Time of the North Atlantic Ocean Heinrich Events}

In the Mediterranean Sea the SST cycles match long-term sea surface water freshening phases by contrast with the North Atlantic Ocean $\delta w$ patterns (Figure 5). During the past $75 \mathrm{kyr}$ the $\delta w$ values in core SU 90-08 increased to a mean $\delta w$ value of $\sim 1.5 \%$. Short-term excursions toward depleted $\delta w$ values occur during the Heinrich events with a longer-term one during the deglaciation. The Mediterranean Sea record is rather 


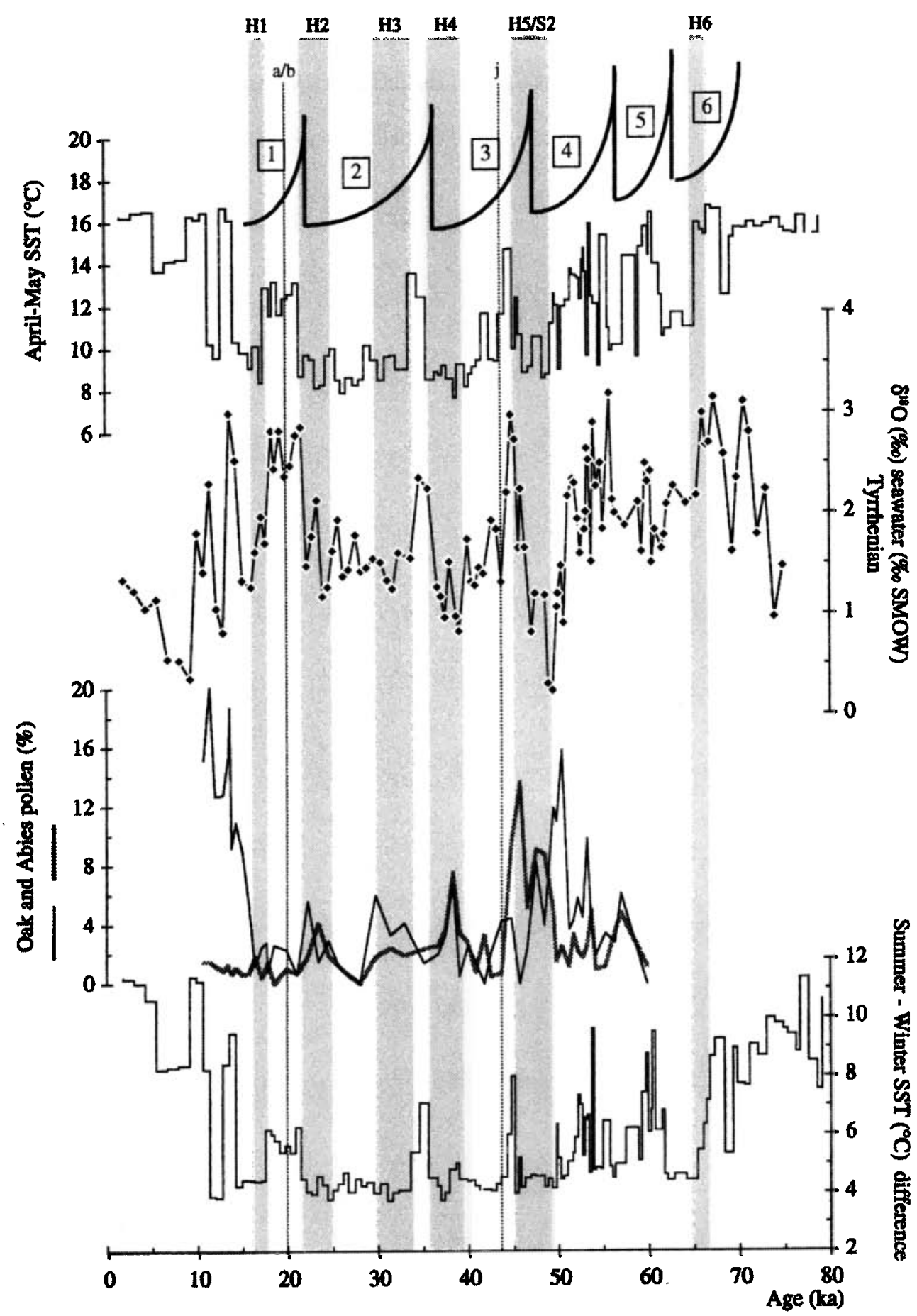

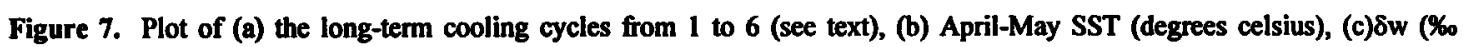
SMOW), (d) Oak (shaded line) and fir tree (solid thin line) pollen abundance (per cent). (Fir tree pollen abundance (per cent) was divided by 3 for graphic convenience), (e) summer to winter SST difference (degrees celsius) as a function of time (ka) in Tyrrhenian Sea core KET 80-03. Position of the Heinrich events, as defined in the text, is also presented.

characterized by several $\delta w$ excursions of large increasing amplitude from the modern value, except at $\sim 8$ and $50 \mathrm{ka}$. The warm to cold SST transitions are marked by gradual $\delta w$ lowerings of the Mediterranean Sea surface waters whereas these periods correspond to short excursions of tow $\delta w$ in the-North
Atlantic Ocean surface waters. Nevertheless, the Mediterranean Sea surface waters recorded low $\delta w$ values at the time of the Heinrich events and therafter a rapid $\delta w$ increase, except after H3, similar to that observed in the North Atlantic Ocean.

The $\delta w$ value was much tower in the Tyrrhenian Sea than in 
the North Atlantic Ocean at $\sim 50 \mathrm{ka}$. The $\delta \mathrm{w}$ difference between both basins was similar to that observed at $\sim 9 \mathrm{ka}$ during sapropel S1 [Kallel et al., 1997b]. In the Tyrrhenian Sea the $\delta w$ decrease slightly preceeded the H5 one by some $2 \mathrm{kyr}$ and could thus be considered as fully contemporaneous taking into account age uncertainties (Figure 5 and Table 2). Nevertheless, several authors reported the presence of a discrete sapropelic layer S2 at the beginning of stage 3 [Ryan, 1971; Cita et al., 1977; Vergnaud-Grazzini et al., 1977, 1986]. Moreover, in core KET 80-03, pollen concentration was augmented at least by a factor of 10 at $50 \mathrm{ka}$ [Rossignol-Strick and Planchais, 1989], which would indicate a reduction of bottom waier oxygenation as was observed during sapropel S1 [Rossignol et al., 1992; Combourieu-Nebout et al., 1998]. At the time of $S 1$ the $\delta w$ departure from the modern value in the Mediterranean Sea is $-0.8 \%$, and salinity may thus be estimated at $\sim 36$, close to the salinity estimate at 36.5 in core SU 90-08 at the same time. Such a salinity pattern would not imply an antiestuarine circulation of the Mediterranean Sea waters, which is neither deduced from benthic $\delta^{13} \mathrm{C}$ records in cores off Portugal [Zahn and Sarnthein, 1987; Zahn et al., 1997] nor from salinity and density gradients between the Mediterranean Sea and the North Atlantic Ocean off the Gibraltar Strait [Duplessy et al., 1992; Kallel et al., 1997a, b]. Hydological changes, observed in the central North Atlantic Ocean core SU 90-08, may differ from those affecting surface waters off the Gibraltar Strait, as observed during the Last Glacial Maximum [Duplessy et al., 1991]. Thus part of the large seawater freshening in the Tyrrhenian Sea at $50 \mathrm{ka}$ may be related to $\mathrm{S} 2$ preceeding $\mathrm{H} 5$.

For the modern conditions the Mediterranean Sea acts as a concentration basin $(\mathbf{P}+\mathbf{R}<\mathbf{E})$, and the modern $\delta w$ difference between the two marine sites is estimated at $-0.6 \%$. At the time of Heinrich events $\mathrm{H} 2-\mathrm{H} 6(20-70 \mathrm{ka})$ the positive difference between the Mediterranean Sea and the North Atlantic Ocean was nearly the same as today (Figure 6). The Mediterranean Sea $\delta w$ changes may thus be considered as a direct response to the inflowing North Atlantic surface waters. Consequently, the modem Mediterranean Sea freshwater balance was not affected at the time of the Heinrich events. During the warm intervals, which follow these events, except after $\mathrm{H} 3$, the $\delta \mathrm{w}$ difference was larger than the modern one because of a larger $\delta w$ increase in the Mediterranean Sea than in the North Atlantic Ocean. Thus the freshwater budget $\mathbf{P}+\mathbf{R}-\mathbf{E}$ decreased as a result of either enhanced evaporation or decreased precipitation and runoff after the Heinrich events. During the transitional periods from warm to cold climatic conditions (cycles 4,3 and 2) the $\delta w$ difference between the two marine regions becomes close to zero. As the $\delta w$ values in the North Atlantic Ocean at core site SU 90-08 seat quasisteadily above the modern $\delta w$ value, the Mediterranean Sea freshwater budget increased either by enhanced precipitation plus runoff or by decrease of the evaporation. During long-term cooling cycle 1 the $\delta w$ difference was nearly constant from 18 to $16 \mathrm{ka}$ and higher than the modern one at $\sim 1.3 \%$. During this period the North Atlantic hydrological changes_were almost transmitted to the Mediterranean Sea, the freshwater budget of which was unchanged, as previously noted [Kallel et al., 1997b].

\section{Discussion}

Pollen analyses in core KET 80-03 [Rossignol-Strick and Planchais, 1989] permit direct comparison of the continental and oceanic climatic changes at the time of the Heinrich events in the Mediterranean area (Figure 7). Among the tree species the dominant types in core KET 80-03, except Pinus, are the deciduous oak, Quercus robur pubescens, and the fir tree, Abies, over the 10-60 ka time span. The modem analogues of the pollen spectra in core KET 80-03 are located in southeastern Europe and middle Asia, and they primarily respond to moisture availability [Rossignol-Strick and Planchais, 1989]. Oak is characteristic of the temperate cool forests of the subhumid and humid Mediterranean altitudinal zones at $200-1300 \mathrm{~m}$, with precipitation ranging from some 600 to $1200 \mathrm{~mm} \mathrm{yr}^{-1}$. Fir trees belong to the cool humid mountainous forest above the deciduous forest.

During the deglaciation, from 10 to $\sim 18 \mathrm{ka}$, oak pollen percentages increased more rapidly than the fir tree percentages. Oak increase is correlated to enhanced SSTs, to high seasonnal contrast, expressed as summer and winter SST difference, and to high sea surface salinity (Figure 7). Inversely, below $18 \mathrm{ka}$, the maximum abundances of oak and fir tree pollen are associated with the warm to cold transitions and to the Heinrich cold climatic events. They thus coincide with periods of a larger freshwater budget than the modem budget and with a moderntype freshwater budget, respectively. The warm post-Heinrich intervals are marked by tree pollen disappearance, when the Mediterranean Sea surface waters recorded a decrease of the freshwater budget. Thus moisture availability, rather than temperature improvement, governs the development of these tree species, as was previously suggested [Rossignol-Strick and Planchais, 1989]. During cold or cooler climatic conditions, model experiments reproduce persistance of the mixed forest (coniferous/temperate deciduous) by a combination of cold winters and cool cloudy summers [Prentice et al., 1992]. Such a model is consistent with the Tyrrhenian Sea palynological and hydrological patterns and with the association of oak and fir tree pollen to periods of low seasonal thermal contrast.

In North America, pollen analyses in a well-dated sequence of Florida revealed moisture increase at the time of the Heinrich events [Grimm et al., 1993]. In the western and southern Europe pollen series, chronology of the climatic changes linked to these events is less constrained [Guiot et al., 1993; Watts et al., 1996a, b]. Rapid increase of arboreal pollen, as seen in the Monticchio Lake in southern Italy, is related to a climatic improvement with temperature and moisture increases and correlated to the postHeinrich SST warming in the North Atlantic Ocean [Watts et al., 1996a]. Although exhibiting similar a alternation of high and low abundance of oak pollen, this continental scheme disagrees with the Tyrrhenian Sea palynological pattern since cold and cooler periods coincide with a higher abundance of arboreal pollen and warm intervals coincide with their reduction. In the marine environment such a reduction could be due to changes of pollen preservation. However, pine tree pollen, a very resistant species to degradation, is present all along the core, and oak and fir tree pollen percentages vary independantly of the pine tree pollen sum [Rossignol and Planchais, 1989]. It cannot either be related to a change of wind directions as the Tyrrhenian Sea core would receive pollen from the close western and/or eastern continental areas. Finally, peaks of abundance of oak and fir tree could be attributed to increased river pollen transport. However, there are few large rivers around the Tyrrhenian Sea. Consequently, the difference between the continental and marine palynological records is likely related to uncertainties on the chronological position of the Heinrich episodes in the continental areas and to 
an overinterpretation in term of temperature of the pollen profiles.

During the Heinrich events the North Atlantic Ocean hydrological changes are directly transferred into the Mediterranean Sea. Massive ice discharges to $\sim 40^{\circ} \mathrm{N}$ into the North Atlantic Ocean led to cold climatic conditions without significant changes of the modern freshwater budget $(\mathbf{P}+\mathbf{R}<\mathbf{E})$ in the Mediterranean area. During the post-Heinrich times the North Atlantic Ocean hydrological changes are amplified in the Mediterranean Sea. The Mediterranean climate was characterized by warm but more arid conditions than today $(\mathbf{P}+\mathbf{R} \ll \mathbf{E})$. During the transitions the hydrological changes in the two marine areas are disconnected. The Mediterranean Sea freshwater budget increased $(\mathbf{P}+\mathbf{R} \gg \mathbf{E})$, while the North Atlantic Ocean hydrology did not vary greatly. Thus, except during the Heinrich events, oceanic circulation changes in the North Atlantic Ocean cannot solely explain the Mediterranean climatic changes by themselves, and reorganization of the atmospheric circulation may be envisaged. Today, the Mediterranean climate is seasonally balanced from a moderate influence of Atlantic lows in winter to the dominance of subtropical highs in summer, so that precipitation and runoff do not equilibrate the dominant evaporation processes. Similar atmospheric conditions may be envisaged at the time of the Heinrich events in the Mediterranean Sea because of the observed modern-type freshwater buget. The changes toward aridity in the post-Heinrich periods may be due to the predominance of the subtropical highs at the mediterranean latitudes, along with a northward latitudinal shift of the Atlantic depressions tracks. Thereafter, during the transitions the Mediterranean area would have been mainly situated on the track of the Atlantic lows, providing cooler and milder conditions. Thus the increase of precipitation before the Heinrich events, at the very northern latitudes of the North Atlantic Ocean and then at northern latitudes, could contribute to the growth of the different ice sheet involved in the massive iceberg discharge. This could, in turn, provide new massive ice sheet calving due to mass instability. Thus one of the causes of ice sheet instability might be searched in the atmosphere toward air masses and water vapor changes [Broecker, 1995].

\section{Conclusion}

During the past 15-75 kyr the Mediterranean Sea surface waters underwent several long-term cooling cycles, ending by abrupt SST increases. This pattern is similar to the SST changes associated to the massive discharge of icebergs into the North Atlantic Ocean, the Heinrich events. The post-Heinrich SST increases in the two oceanic areas are considered synchronous as the overall dating uncertainties do not permit a check of a possible lead of the North Atlantic Ocean SST changes with respect to the Mediterranean ones. By contrast to the open ocean record, the Mediterranean Sea SST cycles matched coeval longterm periods of salinity lowering. The hydrological and palynological records show a coherent pattern of the climatic changes in the Mediterranean area. At the time of the Heinrich events the North Atlantic Ocean hydrological changes were directly transferred to the Mediterranean Sea. Presence of the ice armada at $40^{\circ} \mathrm{N}$ in the North Atlantic Ocean did not affect the Mediterranean freshwater budget, and the Mediterranean Sea acted as a concentration basin as today. Despite the cold climatic conditions, persistance of a mixed forest of coniferous and temperate deciduous trees is observed, likely because of cooler and more humid summers as indicated by the low seasonnal thermal contrast in the Mediterranean regions. The end of the Heinrich events was marked by a salinity increase of larger amplitude in the Mediterranean Sea in the two oceanic areas. The Mediterranean Sea freshwater budget $(\mathbf{P}+\mathbf{R} \ll \mathbf{E})$ consequently decreased, and the resulting aridity limited forest development. During the warm to cold transitions, while the North Atlantic Ocean hydrology at $40^{\circ} \mathrm{N}$ did not greatly change, an increase of the freshwater budget was observed in the Mediterranean Sea along with forest growth. These climatic changes from dry to humid conditions could be related to latitudinal shifts of the Atlantic depression tracks over the Mediterranean area with respect to ice sheet growth and decay.

Acknowledgments. We are greatly indebted to $R$. Zahn and to two anonymous referees for their very helpfull comments. We thank $B$. LeCoat, J. Tessier, E. kaltnecker and N. Tisnerat for their help in isotopic analyses and J. Duprat for micropaleontological analyses. This work was supported by CNRS, CEA, and the CEE Clivamp-MA3-CT95-0043 program. N. K. gratefully aknowledges the support of Ministère Français des Affaires Etrangères and Ministère Tunisien de l'Enseignement Supérieur (projet CMCU). This is LSCE contribution $n^{\circ} 195$.

\section{References}

Andrews J.T., and K. Tedesco, Detrital carbonaterich sediments, northwestern Labrador Sea: Implications for ice-sheet dynamics and iceberg rafting (Heinrich) events in the North Atlantic, Geology, 20, 1087-1090, 1992.

Andrews, T.J., H. Erlenkeuser, K. Tedesco, A. Aksu, and A.J.T. Jull, Late Quatemary (stage 2 and 3) meltwater and Heinrich events, northwest Labrador Sea, Quat. Res., 4I, 26-34, 1994.

Austin, W.E., E. Bard, J.B. Hunt, D. Kroon, and J.D. Peacock, The ${ }^{14} \mathrm{C}$ age of Icelandic Vedde ash: Implications for Younger Dryas marine reservoir age corrections, Radiocarbon, 37, 5362, 1994.

Bard, E., M. Amold, J. Mangerud, M. Paterne, L.
Labeyrie, J. Duprat, M. A. Mélières, E. Sonstegaard, and J.C. Duplessy, The North Atlantic atmosphere-sea surface ${ }^{14} \mathrm{C}$ gradient during the Younger Dryas climatic event, Earth Planet. Sci. Lett., 126, 275-287, 1993.

Bauman, K. H., K. S. Lackschewitz, J. Mangerud, R. F. Spielhagen, T.C.W. Wolf-Welling, R. Heinrich, and H. Kassens, Reflection of Scandinavian ice sheet fluctuations in Norwegian Sea sediments during the past 150,000 years, Quat. Res., 43, 185-197, 1995.

Bond., G., and R. Lotti, Iceberg discharges into the North Atlantic on millennial time scales during the last deglaciation, Science, 267. 1005-1010, 1995.

Bond, G., et al., Evidence for massive discharges of icebergs into the North Atlantic Ocean during the last glacial period, Nature, 360 , 245-251, 1992.

Bond, G., W. Broecker, S. Johnsen, J. McManus, L. Labeyrie, J. Jouzel, and G. Bonani, Correlations between climate records from North Atlantic sediments and Greenland ice, Nature, 365, 143-147, 1993.

Broecker, W., Chaotic climate, Sci. Am., Nov. ,4450, 1995.

Broecker, W., G. Bond, M. Klas, E. Clark, and J. MacManus, Origin of the northern Atlantic's Heinrich events, Clim. Dyn., 6. 265-273, 1992.

Cita, M. B., C. Vergnaud-Grazzini, C. Robert, H. Chamley, N. Ciaranfi, and S. Donofrio, Paleoclimatic record of a long deep-sea core 
from the Eastern Mediterranean, Quat. Res., 8, 205-235, 1977.

Combourieu-Nebout, N., M. Paterne, J.L. Turon, and $\mathbf{G}$. Siani $\mathbf{A}$ high resolution record of the last deglaciation in the central Mediterranean Sea: paleovegetation and paleohydrological evolution. Quat. Sci. Rev, 17, 303-317, 1998.

Cortijo, E., La variabilité climatique rapide dans I'Atlantique Nord depuis 128000 ans: relations entre les calottes de glace et l'océan de surface, Ph. D. thesis, Univ. de Paris-Sud, Paris, France, 1995.

Cortijo, E., L. Labeyrie, L. Vidal, M. Vautravers, M. Chapman, J.C. Duplessy, M. Elliott, M. Amold, J.L. Turon, and G. Auffret, Changes in sea surface hydrology associated with Heinrich event 4 in the North Atlantic Ocean between $40^{\circ}$ and $60^{\circ} \mathrm{N}$, Earth Planet. Sci. Lett., 146, 2945, 1997.

Dansgaard, W., S.J. Johnsen, H.B. Clausen, D. Dahl-Jensen, N.S. Gundestrup, C.U. Hammer, C.S. Hvidberg, J.P. Steffensen, A.E. Sveinbjornsdottir, J. Jouzel, and G. Bond, Evidence for general instability of past climate from a 250-kyr ice-core record, Nature, 364, 218-220, 1993.

Duplessy, J. C., L. D. Labeyrie, A. Juillet-Leclerc, F. Mattre, J. Duprat, and M. Sarnthein, Surface salinity reconstruction of the North Atlantic Ocean during the Last Glacial Maximum, Oceanol. Acta, 14, 311-324, 1991.

Duplessy, J. C., L. D. Labeyrie, M. Paterne, M. Arnold, J. Duprat, and T. C. E. van Weering., Changes in surface salinity of the North Atlantic ocean during the last deglaciation. Nature, 358, 485-487, 1992

Elliot, M., L. Labeyrie, G. Bond, E. Cortijo, J. L. Turon, N. Tisnerat, and J. C. Duplessy, Millennial-scale iceberg discharges in the Iminger Basin during the last glacial period: Relationship with the Heinrich events and environmental settings, Paleoceanography, 13, 433-446, 1998.

Epstein, S., R., Buchsbaum, H. A., Lowenstam, and $H$. C. Urey, Revised carbonate-water isotopic temperature scale, Geol. Soc. Am. Bull., 64, 1315-1325, 1953.

Fronval, T., E. Jansen, J. Bloemendal, and S. Johnsen, Oceanic evidence for coherent fluctuations in Fennoscandian and Laurentide Ice-Sheets on millenium timescales, Nature, 374, 443-446, 1995.

Grimm, E.C., G.L. Jacobson, W.A. Watts, B.C.S. Hansen, and K.A. Maasch, A 50,000-year record of climate oscillations from Florida and its temporal correlation with the Heinrich events, Science, 261, 198-200, 1993.

Grousset, F.E., L. Labeyrie, J.A. Sinko, M. Cremer, G. Bond, J. Duprat, E. Cortijo, and S. Huon, Patterns of ice-rafted detritus in the glacial North Atlantic $\left(40-55^{\circ} \mathrm{N}\right)$, Paleoceanography, 8, 175-211, 1993.

Guiot, J., J.L. de Beaulieu, R. Cheddadi, F. David, P. Ponel, and M. Reille, The climate in Western Europe during the last glacial/interglacial cycle derived from pollen and insect remains, Palaeogeogr. Palaeoclimatol. Palaeoecol., 103, 73-93, 1993.

Gwiazda, R.H., S.R. Hemming, and W.S. Broecker, Provenance of icebergs during Heinrich event 3 and the contrast to their sources during other Heinrich episodes, Paleoceanography, II, 371-378, 1996.
Heinrich, H., Origin and consequences of cycling ice rafting in the northwest Atlantic Ocean during the past 130,000 years, Quat. Res., 29, 142-152, 1988

Hutson, W. H., The Aghulas current during the late Pleistocene: Analysis of modem analogs, Science, 207, 227-238, 1979.

Imbrie, J., J.D. Hays, D.G. Martinson, A. McIntyre, A.C. Mix, J.J, Morley, N.G. Pisias, W.L. Prell, and N.J. Shackleton, The orbital theory of Pleistocene climate: support from a revised chronology of the marine $\delta^{18} \mathrm{O}$ record. Edited by A. Berger et al., in Milankovitch and Climate, Reidel, pp. 269-305, Norwell, Mass., 1982.

Kallel, N., M. Paterne, J.C. Duplessy, C. Vergnaud-Grazzini, C. Pujol, L. Labeyrie, M. Amold, and M. Fontugne, Enhanced rainfall on Mediterranean region during the last Sapropel event, Oceanol. Acta, 20, 697-711, 1997a.

Kallel, N., M. Paterne, L. Labeyrie, J.C. Duplessy, and $M$. Amold, Temperature and salinity records of the Tyrrhenian Sea during the last 18,000 years, Palaeogeogr. Palaeoclimatol. Palaeoecol., 135, 97-108, 1997b.

Labeyrie, L., J.J. Pichon, M. Labracherie, P. Ippolito, J. Duprat, and J.C. Duplessy, Melting history of Antarctica during the past 60,000 years, Nature, 322, 701-706, 1986.

Levitus, S.. Climatological atlas of the world ocean. NOAA Prof. Pap., 13, 1982.

Manighetti, B., I.N. McCave, M. Maslin, and N.J. Shackleton, Chronology for climate change: Developing age models for the biogeochemical ocean flux study cores, Paleoceanography, 10 , 513-526, 1995

Maslin, M.A., N.J. Shackleton, and U. Pflauman, Surface water temperature, salinity, and density changes in the northeast Atlantic during the last 45,000 years: Heinrich events, deep water formation, and climatic rebounds, Paleoceanography, 10, 527-544, 1995.

Mazaud, A., C. Laj, E. Bard, M. Amold, and E. Tric, Geomagnetic field control of ${ }^{14} \mathrm{C}$ production over the last $80 \mathrm{kyr}$; Implications for the radiocarbon time-scale, Geophys. Res. Letter., 18, 1885-1888, 1991.

Oppo, D.W., and S.J. Lehman, Sub-orbital timescale variability of North Atlantic Deep Water during the past 200,000 years, Paleoceanography. J0, 901-910, 1995.

Overpeck, J. T., T. Webb III, and I. C. Prentice, Quantitative interpretation of fossil pollen spectra : dissimilarity coefficients and the method of modern analogs, Quat. Res., 23, 87 108,1985

Paterne, M., F. Guichard, J. Labeyrie, P. Y. Gillot, and J.C. Duplessy, Tyrrhenian Sea tephrachronology of the oxygen isotope record for the past 60000 years, Mar. Geol., 72, 259285, 1986

Paterne, M., F. Guichard, and J. Labeyrie, Explosive activity of the south Italian volcanoes during the past 80000 years as determined by marine tephrochronology, $J$. Volcanol. Geotherm. Res., 34, 153-172, 1988.

Prell, W., The stability of low latitude sea surface temperatures: An evaluation of the CLIMAP reconstruction with emphasis on the positive SST anomalies, Tech. Rep. TR025, 60 pp., U. S. Dep. of Energy, Washington, D.C., 1985.

Prentice, I.C., J. Guiot, and S. P. Harrison,
Mediterranean vegetation, lake levels and paleoclimate at the Last Glacial Maximum, Nature, 360, 658-660, 1992.

Rasmussen, T.L., E. Thomsen, T.C.E. van Weering, and L. Labeyrie, Rapid changes in surface and deep water conditions at the Faeroe Margin during the last 58,000 years, Paleoceanography, 11, 757-771, 1996.

Revel, M., J.A. Sinko, F. Grousset, and P.E. Biscaye, $\mathrm{Sr}$ and $\mathrm{Nd}$ isotopes as tracers of North Atlantic lithic particles: Paleoclimatic implications, Paleoceanography, 11, 95-113, 1996.

Rossignol-Strick, M., and N. Planchais, Climate patterns revealed by pollen and oxygen isotope records of a Tyrrhenian Sea core, Nature, 342, 413-416, 1989

Rossignol-Strick, M. , N. Planchais, M. Paterne and D. Duzer. Vegetation dynamics and climate during the deglaciation in the South Adriatic basin from a marine record, Quat. Sci. Rev., /I, 415-423, 1992.

Ruddiman, W.F., Late Quatemary deposition of ice-rafted sand in the subpolar North Atlantic (lat. $40 \mathrm{~N}$ to $65 \mathrm{~N}$ ), Geol. Soc. Am. Bull., 88 , 1813-1827, 1977.

Ryan, W.B.F., Stratigraphy of late Quaternary sediments in the eastern Mediterranean, inThe Mediterranean Sea, edited by Dowden, pp. 149-169, Van Nostrand Reinhold, New York, 1971.

Sarnthein, M., K. Winn, S. Jung, J.C. Duplessy, L. Labeyrie, H. Erlenkeuser, and G. Ganssen, Changes in east Atlantic Deepwater circulation over the last 30,000 years: Eight time slice reconstructions, Paleoceanography, 9, 209 . $267,1994$.

Shackleton, N. J., Attainment of isotopic equilibrium between ocean water and the benthonic foraminifera genus Uvigerina: Isotopic changes in the ocean during the last glacial, Coll. CNRS 219, Cent. Nat. de la Rech. Sci., Paris, pp 203-210, 1974.

Smythe, F.W., W.F. Ruddiman, and D.N. Lumsden, Ice-rafted evidence of long-term North Atlantic circulation, Mar. Geol., 64 131-141, 1985.

Stuiver, M., and P.J. Reimer, Extended ${ }^{14} \mathrm{C}$ database and revised calib $3.0{ }^{14} \mathrm{C}$ age calibration program, Radiocarbon, 35, 215 230, 1993.

Vautravers, M., Sédimentation et dissolution des carbonates biogéniques aux moyennes latitudes Nord et Sud: Approche quantitative et relations avec les paléociculations océaniques des derniers 150000 ans, Ph. $-D$. thesis, Univ. de Bordeaux -I, Talence, France, 1997.

Vergnaud-Grazzini, C., W. B. F. Ryan, and M. B. Cita, Stable isotope fractionation, climate change and episodic stagnation in the Eastern Mediterranean during the late Quaternary, Mar. Micropaleontol., 2, 353-370, 1977.

Vergnaud-Grazzini, C., M. Devaux, and J. Znaidi, Stable isotope "anomalies" in the Mediterranean Pleistocene records, Mar. Micropaleontol., 10, 35-69, 1986.

Vidal, L., L. Labeyrie, E. Cortijo, M. Amold, J.C. Duplessy, E. Michel, S. Becqué, and T.C.E. van Weering, Evidence for changes in the North Atlantic Deep Water linked to meltwater surges during the Heinrich events, Earth Planet. Sci Lett., 146, 13-27, 1997.

Vidal, L., L. Labeyrie, and T.C.E. van Weering. 
Benthic $\delta^{180}$ records in the North Atlantic over the last glacial period $(60-10 \mathrm{kyr})$ : Evidence for brine formation, Paleoceanography, 13, 245-251, 1998.

Watts, W.A., J.R. M. Allen, and B. Huntley, Vegetation history and paleoclimate of the last glacial period at Lago Grande di Monticchio, southern Italy, Quat. Sci. Rev., I5, 133-153, $1996 a$.

Watts, W.A., J.R. M. Allen, B. Huntley, and S.C. Fritz, Vegetation history and climate of the last 15,000 years at Laghi di Monticchio, southem Italy, Quat. Sci. Rev., 15, 113-132, 1996b.

Zahn, R., and $\mathbf{M}$. Samthein, Benthic isotope evidence for changes of the Mediterranean outflow during the late Quaternary, Paleoceanography, 2, 543-559, 1987.

Zahn, R., J. Schoenfeld, R. Kudrass, M.H. Park, H. Erlenkeuser, and P. Grootes, Thermohaline instability in the North Atlantic during meltwater events: Stable isotope and ice-rafted detritus records from core SO75-26KL, Portuguese margin, Paleoceanography, 12, 696-710, 1997.

M. Amold, E. Cortijo, J.C. Duplessy, M. Fontugne, L. Labeyrie, and M. Paterne, Laboratoire des Sciences du Climat et de I'Environnement, Unité mixte CNRS-CEA, 91198
Gif sur Yvette, France. (Martine.Paterne@ lsce cnrs-gif.fr)

N. Kallel, Département des Sciences de la Terre, Université de Sfax, Laboratoire E08/C10, Route de Soukra, 3038 Sfax, Tunisia.

M. Rossignol-Strick, Laboratoire de Paléontologie et Palynologie, Box 106, Université Pierre et Marie Curie, 75005 Paris, France.

M. Vautravers, Département de Géologie et Océanographie, Université de Bordeaux I, 33405 Talence, France.

(Received December 9, 1997; revised October 7, 1998 , accepted December 2, 1998.) 